FEDERAL RESERVE BANK OF SAN FRANCISCO

WORKING PAPER SERIES

\title{
China's monetary policy and the exchange rate
}

\author{
Aaron Mehrotra \\ Bank of Finland \\ José R. Sánchez-Fung \\ Bank of Finland
}

July 2010

Working Paper 2010-19

http://www.frbsf.org/publications/economics/papers/2010/wp10-19bk.pdf

The views in this paper are solely the responsibility of the authors and should not be interpreted as reflecting the views of the Federal Reserve Bank of San Francisco or the Board of Governors of the Federal Reserve System. This paper was produced under the auspices for the Center for Pacific Basin Studies within the Economic Research Department of the Federal Reserve Bank of San Francisco. 


\section{BOFIT Discussion Papers \\ $10 \bullet 2010$}

Aaron Mehrotra and José R. Sánchez-Fung

China's monetary policy and the exchange rate

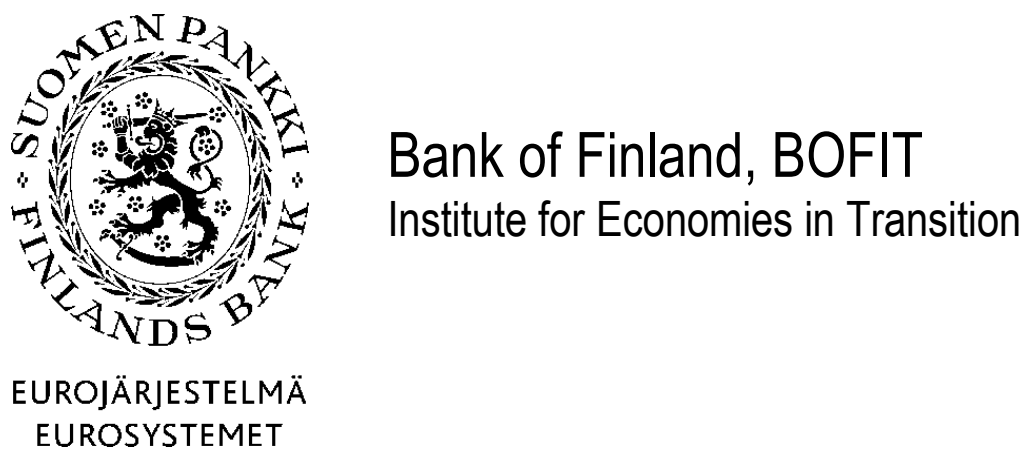


BOFIT Discussion Papers

Editor-in-Chief Aaron Mehrotra

BOFIT Discussion Papers 10/2010

19.7.2010

Aaron Mehrotra and José R. Sánchez-Fung: China's monetary policy and the exchange rate

ISBN 978-952- 462- 685-9

ISSN 1456-5889

(online)

This paper can be downloaded without charge from

http://www.bof.fi/bofit

or from the Social Science Research Network electronic library at http://ssrn.com/abstract_id=.

Suomen Pankki

Helsinki 2010 


\section{Contents}

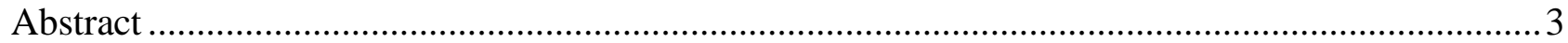

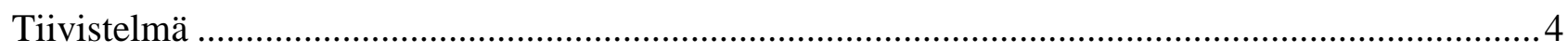

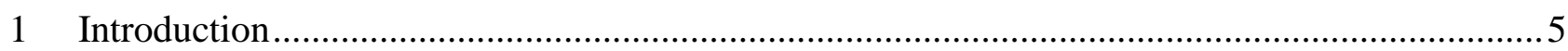

2 Specifying a McCallum-Taylor reaction function ...................................................... 6

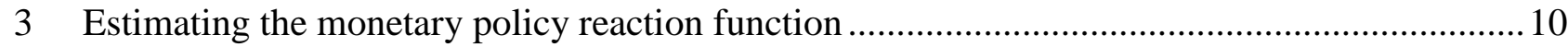

4 Monetary policy reactions and survey-based inflation expectations .................................... 18

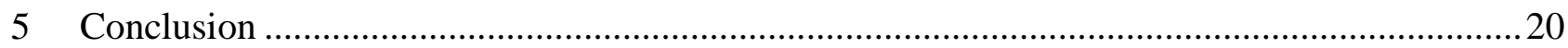

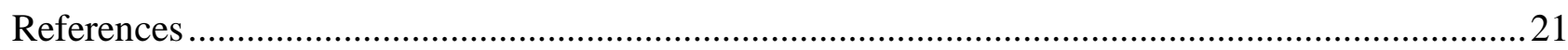


All opinions expressed are those of the authors and do not necessarily reflect the views of the Bank of Finland. 


\section{Aaron Mehrotra* and José R. Sánchez-Fung**}

\section{China's monetary policy and the exchange rate ${ }^{1}$}

\section{Abstract}

The paper models monetary policy in China using a hybrid McCallum-Taylor empirical reaction function. The feedback rule allows for reactions to inflation and output gaps, and to developments in a trade-weighted exchange rate gap measure. The investigation finds that monetary policy in China has, on average, accommodated inflationary developments. But exchange rate shocks do not significantly affect monetary policy behavior, and there is no evidence of a structural break in the estimated reaction function at the end of the strict dollar peg in July 2005. The paper also runs an exercise incorporating survey-based inflation expectations into the policy reaction function and meets with some success.

JEL classification codes: E42, E52.

Keywords: Exchange rate; hybrid McCallum-Taylor monetary policy reaction function; SVAR; survey-based inflation expectations; China.

Acknowledgements: We thank Tuuli Koivu, likka Korhonen, an anonymous referee, participants in the 2010 American Economic Association-ASSA Annual Meetings in Atlanta, ACES session on China's exchange rate, in the 2010 Finnish Economic Association Annual Meeting in Tampere, and in the Chinese Economist Society's Annual Conference in Xiamen, in particular our discussants Sushanta Mallick, Petri Mäki-Fränti and Yufei Yuan, for helpful comments and suggestions. All opinions are the authors' and do not necessarily reflect those of the Bank of Finland. Any errors are our own.

Address for correspondence.

* Bank of Finland, Institute for Economies in Transition (BOFIT), PO Box 160, FI-00101, Helsinki, Finland. E-mail: aaron.mehrotra@bof.fi.

** School of Economics, Kingston University, Penrhyn Road, Kingston-upon-Thames, Surrey, KT1 2EE, UK. E-mail: j.sanchez-fung@kingston.ac.uk.

\footnotetext{
${ }^{1}$ Forthcoming in Comparative Economic Studies.
} 


\section{Aaron Mehrotra and José R. Sánchez-Fung}

\section{China's monetary policy and the exchange rate}

\section{Tiivistelmä}

Tutkimuksessa mallinnetaan Kiinan rahapolitiikkaa käyttämällä empiiristä hybridiä McCallumin Taylorin reaktiofunktiota. Tämän säännön mukaan rahapolitiikka reagoi inflaatio- ja tuotantokuiluihin sekä kauppapainotetun valuuttakurssikuilun liikkeisiin. Tutkimuksen mukaan Kiinan rahapolitiikka on keskimäärin mukautunut inflaation muutoksiin. Mutta valuuttakurssisokit eivät merkittävästi vaikuta rahapolitiikan asetantaan, eikä estimoidussa reaktiofunktiossa tapahtunut rakenteellista muutosta tiukan dollarikytköksen loputtua heinäkuussa 2005. Tutkimuksessa myös sisällytetään kyselytutkimukseen perustuvia inflaatio-odotuksia politiikkareaktiofunktioon.

Asiasanat: valuuttakurssi, hybridi McCallumin-Taylorin rahapolitiikan reaktiofunktio, SVAR, kyselytutkimukseen perustuvat inflaatio-odotukset, Kiina 


\section{Introduction}

China's emergence as a global power raises concerns about its economic policies. Monetary policy commands attention, since maintaining low inflation is crucial for social and economic stability. High inflation could erode the value of Chinese households' large savings in domestic banks broad money M2 amounted to over $150 \%$ of GDP in 2008. And China's policymakers are also concerned about sustaining rapid economic growth. Hence considering a central bank loss function including inflation and output gaps, as in Svensson (1999), is likely to further our understanding of the conduct of monetary policy in China. But China's institutional features, in particular the limited role of interest rates in the monetary transmission mechanism, precludes estimating benchmark monetary policy reaction functions popular for analyzing more advanced economies.

The paper models monetary policy in China using a hybrid McCallum-Taylor reaction function (McCallum, 2000; Sánchez-Fung, 2005). The main question we seek to answer is: How does the People's Bank of China react to developments in the economy, in particular to output, inflation and exchange rate gaps? In tackling that question, the investigation estimates reaction functions to capture the monetary authorities' adjustments of the monetary base in reaction to the variables of policy interest. The econometric modeling also estimates a reaction function incorporating a survey-based measure of inflation expectations.

Discussions about China's monetary policy have largely focused on the exchange rate, especially in the context of the 2007-2009 crises where the country's dollar peg was thought to be important in feeding the global imbalances (Corden, 2009). That is why China's decision of returning to a de facto dollar peg in the summer of 2008 generated criticism. In principle, the problem is that fixing the exchange rate renders domestic interest rate policy ineffective in the presence of full capital mobility. But China's capital controls have been largely binding, so that determining the link between movements in the exchange rate and domestic monetary policy is an empirical matter.

Previous studies use quantity-based rules in modeling China's monetary policy, but the ultimate aim was different from the present study. Burdekin and Siklos (2008) examine whether Chinese monetary policy could be modeled using a McCallum-type rule. They first compare the outcomes for money growth in China to those suggested by the McCallum rule, and use the data for estimating the coefficients for the policy rule. Koivu et al. (2009) use a McCallum-type rule to forecast inflation in China. Liu and Zhang (2007) used a quantity-based rule as part of a NewKeynesian model to analyze monetary policy in China. 
Zhang (2009) compares price and quantity rules in a dynamic stochastic general equilibrium framework for China, and finds evidence that the impact of a price rule in the economy have become more important. He further argues that, when hit by shocks, following a price rule reduces volatility in the economy. But the policy rules examined in the study do not include the exchange rate as a target variable. Zhang (2009) also includes forward-looking inflation terms in the policy rules, but these are based on actual (instrumented) inflation outcomes rather than on surveys.

We find that monetary policy in China has been procyclical in terms of reactions to inflation. The finding matches the fact that accelerated reform policies have generally coincided with increases in bank lending and inflation pressures (Naughton, 2007). But there is evidence of stabilizing policy via reactions to the output gap, and that may reflect the importance to the authorities of supporting economic growth and employment. Importantly, exchange rate shocks do not seem to significantly impact domestic monetary policy. The outcome probably reflects effective capital controls, which have allowed for conducting a largely independent monetary policy in China. There is no evidence of a structural break, in terms of the estimated monetary policy reaction function, following the end of the strict dollar peg in July 2005.

The paper also includes survey-based inflation expectations in the Chinese monetary policy reaction function. Using business surveys to evaluate the relevance of including forwardlooking elements in the estimated equations produces evidence of stabilizing policy in terms of inflation. But the finding is dependent on the measure of inflation expectations.

The paper proceeds as follows. Section 2 specifies the empirical monetary policy reaction function, relating it to the specific features of China's monetary policy and institutions. Section 3 contains the econometric modeling of the benchmark reaction functions. Section 4 estimates an empirical monetary policy reaction function including a survey-based measure of inflation expectations. Section 5 concludes.

\section{Specifying a McCallum-Taylor reaction function}

The paper models monetary policy in China using the type of hybrid McCallum-Taylor reaction function studied in Sánchez-Fung (2005) (see also McCallum, 2000). The central bank controls the growth of the monetary base $\Delta b$ according to the following feedback mechanism

$\Delta b=\alpha+\beta_{1}\left(y-y^{*}\right)+\beta_{2}\left(\pi-\pi^{*}\right)+\beta_{3}\left(e-e^{*}\right)+u$ 
In equation (1) $\left(y-y^{*}\right)$ is the output gap measured as the difference between actual and potential output; $\left(\pi-\pi^{*}\right)$ is the inflation gap, i.e. the difference between actual inflation and the pre-announced annual inflation target. The gap $\left(e-e^{*}\right)$ gives the nominal trade-weighted exchange rate's deviations from a long-run trend path.

The monetary base is the relevant instrument under the control of the policymaker (McCallum, 1988). Interest rates - only infrequently adjusted - have traditionally played a small role in China's monetary transmission mechanism. The authorities announce a variety of interest rates, such as a bank lending rate, rediscount rate and benchmark rates for loans and deposits of different maturities. But overall the liberalization of interest rates has proceeded slowly.

In contrast to the limited role of interest rates, intermediate annual money supply targets for M2 have been announced from the mid-1990s. The People's Bank targets a level of the money supply so as to prevent inflation and deflation (PBoC, 2005). Reserve requirement ratios have been adjusted in order to control the money supply, together with open market operations in treasury bonds and central bank bills. The choice of instrument for analysis here corresponds with previous work on China's monetary policy, e.g. Burdekin and Siklos (2008), Koivu et al. (2009), and Koźluk and Mehrotra (2009). Operating a fixed exchange rate along with strict capital controls has enabled implementation of a fairly independent monetary policy (e.g. Ma and McCauley, 2008). Majority state ownership of the banking sector arguably facilitates sterilization of capital inflows. ${ }^{2}$ Formal credit plans formed the basis of commercial bank lending until 1998. Window guidance policy continues to play an important role in Chinese monetary policy, which includes direct guidelines from central bank to commercial banks on lending to the money-holding sector ${ }^{3}$.

The target variables on the right hand side of (1) are rationalized by the formal objectives of the People's Bank of China. The announced objective of Chinese monetary policy is to "maintain the stability of the value of the currency and thereby promote economic growth". ${ }^{4}$ While the specification of a final target suggests that the value of the currency is important, promoting economic growth is in line with the Chinese government's concern for providing sufficient employment and maintaining social stability. This supports inclusion of the output gap in equation (1). As an expanding output gap may result in inflationary pressures, its inclusion is justified also on the basis of maintaining price stability.

\footnotetext{
${ }^{2}$ Liu and Zhang (2007) note that there have been persistent deviations from uncovered interest rate parity.

${ }^{3}$ For a thorough description of China's monetary policy see Geiger (2008); Evenett (2010) discusses China's exchange rate policy.

${ }^{4}$ http://www.pbc.gov.cn/english/huobizhengce/objective.asp
} 
In estimating the output gap in China the analysis applies a Hodrick-Prescott filter to yearon-year growth rates of industrial production, with a conventional smoothing parameter of 1,600. ${ }^{5}$ Holz (2004) notes that China's data collection is most advanced for the industrial sector. Industry covered 47\% of China's GDP both at the start (1994) and end (2008) of our estimation sample. There is also a strand of research related to the limitations and reliability of Chinese GDP statistics (Rawski, 2001; Holz, 2008). Recent important revisions to GDP data -in particular the 17\% upward adjustment to its level in late 2005- have been due to corrections regarding the size of the service sector.

China does not operate a formal inflation targeting regime, but annual targets for CPI growth are set by the Central Economic Working Conference. We employ that measure in constructing the inflation gap. ${ }^{6}$ For 1994-1997, targets were only defined for retail price inflation (RPI), a variable that is closely correlated with CPI inflation. For those years, CPI inflation targets are constructed using the announced RPI inflation target and adding the gap between actual CPI and RPI inflation for the previous year. ${ }^{7}$ The inflation gap has been negative during most of the sample, as actual inflation has fallen short of the target. Positive inflation gaps have been largely a temporary phenomenon, arising with demand pressures and high lending growth in 1994/95, and in tandem with food price pressures in 2004 and 2007/2008. Figure 1 displays the inflation gap together with the output gap, both series divided by their respective standard deviations. Some co-movement between the two series can be seen for 1994, 2004 and 2008.

\footnotetext{
${ }^{5}$ While an industrial production series in levels is available in current prices, no deflator is published; hence our choice of year-on-year growth rates (in constant prices) for construction of the output gap. Moreover, during the reform period, Chinese economic cycles have been "growth cycles", with slowdowns and upturns in growth rates but no fall in the levels series.

${ }^{6}$ The data are from the China Monetary Policy Report, from 2001 onwards (various issues). The targets prior to 2001 were obtained from the website of the National People's Congress of China (only in Chinese, link available from the authors upon request).

${ }^{7}$ For 1998, when both RPI and CPI targets were announced by the government, this procedure produces a CPI target equal to the officially announced target.
} 
Figure 1 Output gap and inflation gap

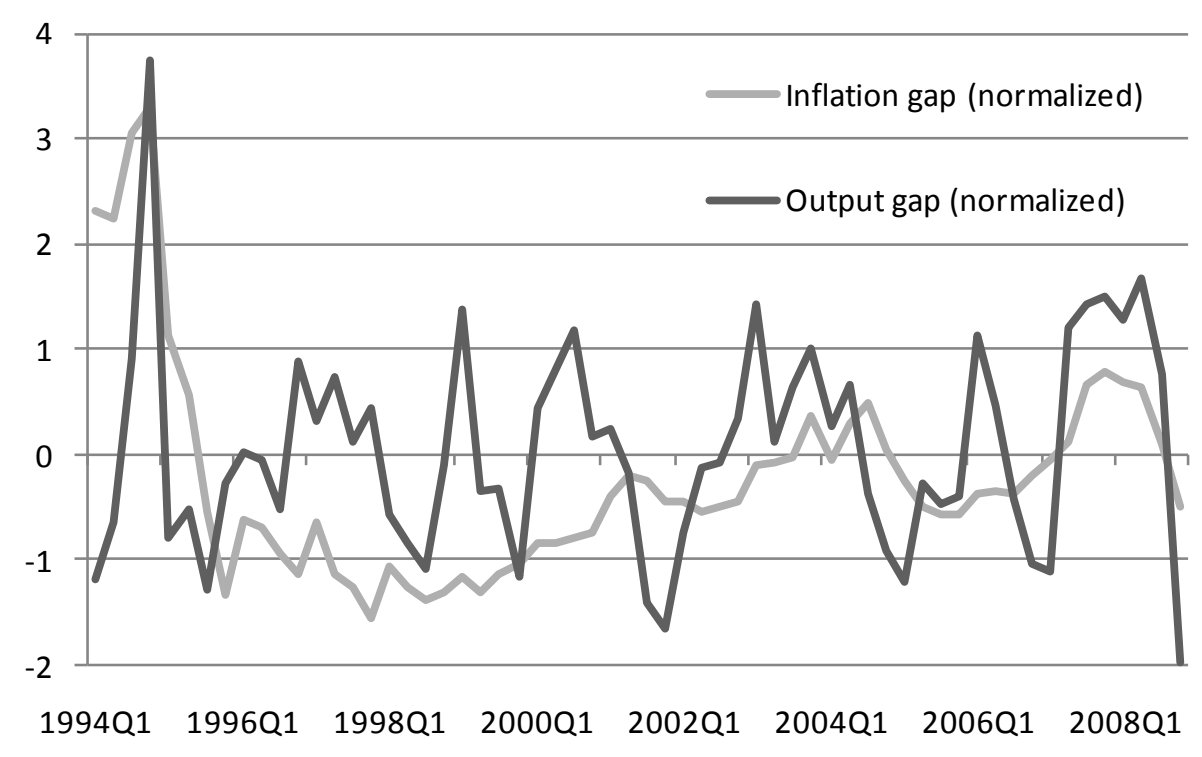

Note: Both series are normalized by their respective standard deviations.

The final gap in equation (1) is the exchange rate gap. China has tightly controlled the value of the yuan against the dollar, even after the strict dollar peg was disbanded in July 2005. The fixed exchange rate arrangement makes China different from some other transition economies (see e.g. Granville and Mallick, 2010, for evidence on the role of the exchange rate in Russian monetary policy). The existence of the strict peg during most of the sample ruled out use of the bilateral rate in the econometric modeling. The model produces the impacts of the trade-weighted nominal exchange rate, which is not an operating target, on China's monetary policy. The rate is important from a policy perspective, as it captures imported inflation pressures and changes in competitiveness more extensively than a bilateral exchange rate. The exchange rate gap is defined as the deviation of a trade-weighted exchange rate from its trend. This measure abstracts from the trend appreciation affecting an emerging economy with rapid productivity growth and the ensuing BalassaSamuelson effect. 


\section{Estimating the monetary policy reaction function}

The research plan involves estimating a hybrid McCallum-Taylor policy rule using vector autoregressions (VARs). The strategy allows starting from a single equation specification by focusing on part of the estimated system and subsequently examining richer dynamics via an impulse response analysis. The starting point is a benchmark reduced-form vector autoregression:

$x_{t}=A_{1} x_{t-1}+\cdots+A_{p} x_{t-p}+u_{t}$.

In (2), the $x_{t}$ is a $(K \times 1)$ vector of endogenous variables, the $A_{p}$ are fixed $(K \times K)$ coefficient matrices, and $u_{t}$ is assumed to follow a $K$-dimensional white noise process with $\mathrm{E}\left(u_{t}\right)=0$. A fourvariable VAR is estimated, including output gap $\left(y-y^{*}\right)$, inflation gap $\left(\pi-\pi^{*}\right)$, annualized quarter-on-quarter change in monetary base $\Delta b$, and nominal exchange rate gap $\left(e-e^{*}\right)$. Applying an augmented Dickey-Fuller test reveals that all the series are stationary: a unit root can be rejected for all series at the $10 \%$ level when the Akaike information criterion is used to determine lag length, and for the exchange and output gap a unit root can be rejected at the $1 \%$ level. ${ }^{8}$ Summary statistics for the variables are shown in Appendix A.

The time series data are for 1994Q1 to 2008Q4, but estimations begin at 1994Q2, due to the use of first-differenced data for monetary base. Year 1994 is an important year in terms of reforms, as the former dual exchange rate system gave way to a single exchange rate framework, the fiscal system underwent a revamping, and policy banks were created to differentiate policy-related financing from commercially-oriented activities.

The VARs include three lags, to allow for one full year of dynamics in the level of the monetary base, and estimate the system using ordinary least squares. The system includes a constant and a linear trend. The modeling process reduces the estimated VARs to a parsimonious system by sequentially eliminating all coefficients with $t$-values below the threshold of 1.00 , at each step reestimating the system and deleting the coefficient with the lowest $t$-value. The resulting system, es-

\footnotetext{
${ }^{8}$ When the Schwarz information criterion is used, a unit root can be rejected at $1 \%$ level for monetary base as well. Detailed results are available from the authors upon request.
} 
timated with feasible generalized least squares, passes the major misspecification tests for autocorrelation and ARCH effects. ${ }^{9}$

The equation for the monetary base is the following (with standard errors in parentheses)

$$
\begin{gathered}
\Delta b_{t}=-2.207\left(y-y^{*}\right)_{t-1}+3.055\left(\pi-\pi^{*}\right)_{t-1}-0.146 \Delta b_{t-1}-2.073\left(\pi-\pi^{*}\right)_{t-2}+0.183 \Delta b_{t-2} \\
(0.996) \\
(1.017)
\end{gathered}
$$

The estimated equation for the monetary base suggests that the People's Bank conducts a countercyclical policy, leaning against the wind, in terms of the output gap: an increase in the output gap leads to slower growth of the monetary base. ${ }^{10}$ But the result for the inflation gap is the opposite: inflation above the government's target leads to an increase in the rate of change in monetary base, suggesting that policy is accommodating increases in inflation. ${ }^{11}$ The latter finding is parallel to the argument by Naughton (2007) that demand for real resources has been accommodated by credit policy, which has then led to inflation. But as the inflation gap has been mostly negative during most of our sample period, inflation has not posed a problem for policy makers in China. ${ }^{12}$ The reaction of monetary base growth to the exchange rate gap is accommodative: exchange rate appreciation leads to a fall in base money growth.

How do the results look if we assume the existence of an interest rate rule and replace the growth in base money in the VAR by the People's Bank of China's benchmark one-year lending rate $?^{13}$ The resulting equation for the interest rate in the VAR is as follows:

\footnotetext{
${ }^{9}$ The adjusted Portmanteau test for autocorrelation yields a test statistic of 253.24 ( $p$-value of 0.14 ), and the LM test for autocorrelation with 4 and 1 lags amounts to $76.11(0.60)$ and $9.24(0.90)$, respectively. The multivariate ARCH-LM test yields a test statistic of 510.00, with a $p$-value of 0.37 .

${ }^{10}$ The result is obtained by calculating the long-run impact, i.e. adding up the lagged coefficients of the output gap.

${ }^{11}$ Burdekin and Siklos (2008) find a procyclical response of monetary policy to movements in nominal GDP. However, they do not estimate policy reactions to movements in real output and inflation separately.

12 According to the International Monetary Fund (2003), both transitory and long-term supply shocks contributed to deflation in China in the late 1990s and early 2000s.

${ }^{13}$ Dai (2006) reports that the PBoC would have adopted interest rates as the intermediate goal in 2004. Nevertheless, in 2009, intermediate targets for monetary aggregates and credit growth were announced by the PBoC. Furthermore, base money can be used as an instrument even with a change in the intermediate target by the monetary authority.
} 
$i_{t}=1.137 i_{t-1}-0.023\left(e-e^{*}\right)_{t-1}-0.244 i_{t-2}-0.043\left(y-y^{*}\right)_{t-3}$

$\begin{array}{llll}(0.141) \quad(0.023) & (0.137) \quad(0.028)\end{array}$

$+0.034\left(\pi-\pi^{*}\right)_{t-3}+0.940-0.007 t$

(0.361) (0.004)

In addition to the statistically significant coefficients on lagged interest rates - suggesting important instrument smoothing - and the deterministic terms, only the coefficient on the inflation gap is statistically significant at the $10 \%$ level. Further, while its sign would actually suggest a countercyclical policy response, the magnitude of the coefficient is small. The evidence shows that an interest rate rule does not provide an adequate description of monetary policy behavior in China, at least during the sample considered in the study. The finding is in line with the observation by Liu and Zhang (2007) that a standard Taylor rule does not capture China's interest rate movements well during 1992-2006. We therefore continue with the benchmark system with monetary base as the central bank's instrument.

The analysis examines the system's dynamics by shocking the VARs and computing impulse responses. If we do not want to take a strong stand on the contemporaneous restrictions to identify the system, we could in principle compute forecast error impulse responses (e.g., Breitung et al., 2004). This option creates similar dynamics, as suggested by equation (3), i.e. policy is leaning against the wind in terms of the output gap and accommodative in terms of the inflation and exchange rate gaps. ${ }^{14}$

However, the correlation matrix provides evidence against choosing forecast error impulse responses: the residuals appear contemporaneously correlated, and the correlations in many cases exceed $\pm 2 / \sqrt{T}$, where $T$ is the sample length. Under such conditions, shocks to the system would not happen in isolation. So the analysis opts for structural impulse responses with contemporaneous restrictions, in particular the AB model by Amisano and Giannini (1997). Denoting the structural form errors as $\varepsilon_{t}$ and the reduced form disturbances as $u_{t}$ as before, the model $A u_{t}=B \epsilon_{t}$ is written as

\footnotetext{
${ }^{14}$ The results can be obtained from the authors upon request.
} 


$$
\left[\begin{array}{cccc}
1 & * & 0 & 0 \\
0 & 1 & 0 & * \\
0 & 0 & 1 & * \\
* & * & * & 1
\end{array}\right]\left[\begin{array}{l}
u_{t}^{\pi} \\
u_{t}^{m} \\
u_{t}^{y} \\
u_{t}^{e}
\end{array}\right]=\left[\begin{array}{llll}
* & 0 & 0 & 0 \\
0 & * & 0 & 0 \\
0 & 0 & * & 0 \\
0 & 0 & 0 & *
\end{array}\right]\left[\begin{array}{c}
\epsilon_{t}^{\pi} \\
\epsilon_{t}^{m} \\
\epsilon_{t}^{y} \\
\epsilon_{t}^{e}
\end{array}\right]
$$

where * denotes an unrestricted element.

The structural shocks are an output shock $\epsilon_{t}^{y}$, a price shock $\epsilon_{t}^{\pi}$, a monetary policy shock $\epsilon_{t}^{m}-$ defined as a shock to monetary base - and an exchange rate shock $\epsilon_{t}^{e}$. The structure of system (5) implies that the effective exchange rate gap, being determined largely outside of China, is allowed to react immediately to any shock hitting the system. The assumption is reasonable as we are not using the bilateral USD-yuan rate that was stable during a major part of the estimation sample. The monetary policy reaction function -corresponding to the second row in (5)- is constructed taking account of the policy maker's information set. While information about the exchange rate is available immediately, data on output and inflation gaps are only available with a lag.

The output gap appears in the third row and is specified to react slowly to shocks hitting the system, possibly due to pre-determined consumption and investment expenditure, as in Rotemberg and Woodford (1999). But the output gap reacts rapidly to exchange rate shocks, to avoid over-identifying the system. ${ }^{15}$ The inflation gap reacts slowly to shocks in output or the exchange rate. A slow response is in line with a standard Calvo-pricing scheme where prices are changed at exogenously determined random intervals (Calvo, 1983), or due to menu costs. There is a policy dimension to the inflation gap variable since it incorporates the government's inflation target. So the inflation gap is allowed to react contemporaneously to a monetary policy shock. As there are $K=4$ endogenous variables, and $K(K-1) / 2$ restrictions are necessary for exact identification, the system (5) is just-identified.

The structural model is estimated using the variance-covariance matrix of the reduced form VAR, with a maximum likelihood estimator and scoring algorithm. Figure 2 shows the structural impulse responses 12 quarters ahead. The impulse response graphs show the path of monetary base growth following the various shocks. Appendix B shows the impulse responses computed using the system. In order to illustrate the uncertainty related to the parameter estimates, the graphs display

\footnotetext{
${ }^{15}$ Restricting the coefficient on the exchange rate shock to zero is not supported by the data, judging by the test on overidentifying restrictions.
} 
Hall's 95\% percentile intervals, obtained by bootstrapping methods with 1,000 replications (Breitung et al., 2004).

Figure 2 Responses of base money growth to various shocks
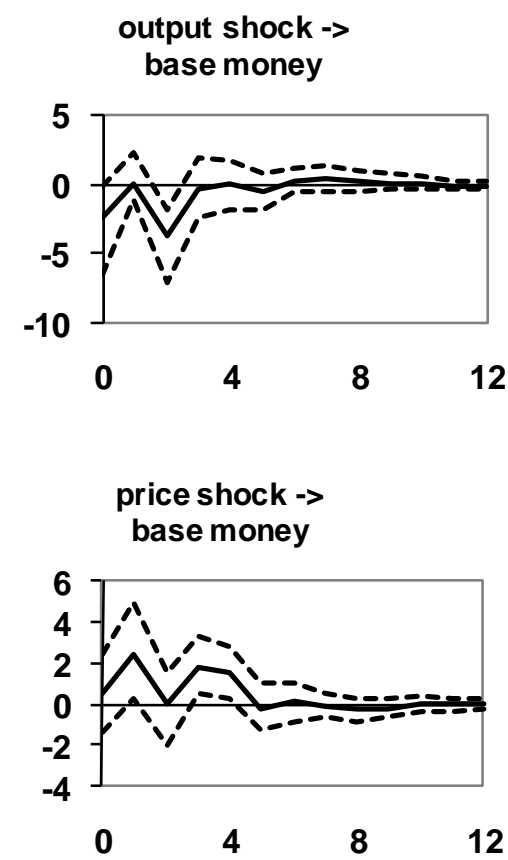

exchange rate shock -> base money

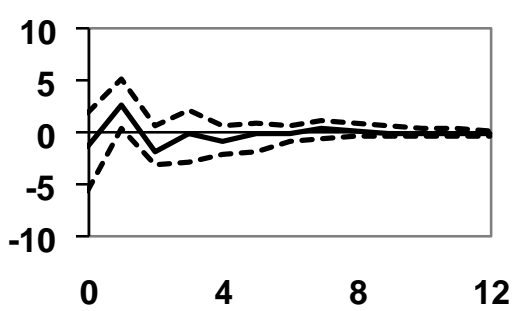


The structural impulse responses partly confirm the results from the monetary base equation of the reduced form VARs: policy is accommodative in terms of an inflation shock and countercyclical in terms of an output shock. The latter finding supports the common perception about the importance of growth and employment for China's policymakers. However, domestic monetary policy does not appear to be very responsive to movements in the exchange rate. ${ }^{16}$ This may be the result of relatively binding capital controls, which provide leeway for domestic policy despite the fixed exchange rate, or the possibility to sterilize capital inflows without major implications for domestic interest rates.

It is of interest to consider the robustness of the responses in Figure 2 to changes in the structure of the estimated SVAR model. In particular, we investigate the responses to shocks in a system with a Cholesky decomposition of the variance-covariance matrix and the following two orderings of the variables: $\left\{\left(y-y^{*}\right),\left(\pi-\pi^{*}\right), \Delta b,\left(e-e^{*}\right)\right\}$ and $\left\{\left(e-e^{*}\right), \Delta b,\left(\pi-\pi^{*}\right),\left(y-y^{*}\right)\right\}$. The procyclical response to the inflation gap detected in the benchmark system remains when adopting the alternative models. With the first ordering, the response of policy to an output shock appears to be procyclical and with both orderings there is evidence of a procyclical policy response to the exchange rate. However, there is little theoretical support for the second ordering of variables. ${ }^{17}$

The exercise also considers a five-variable VAR including the benchmark one-year lending rate: in this system movements in the monetary aggregate should be negatively correlated with interest rates. In the reduced form equations, base money never enters the equation for interest rates with a statistically significant coefficient. The interest rate enters the equation for base money with a counterintuitive positive coefficient. It is difficult to identify shocks in the SVAR methodology including both base money and interest rates, as it is not clear how to simultaneously identify the (assumed) policy shocks. However, simple forecast error impulse responses indicate that there is no statistically significant impact of a base money shock on the interest rate. This result is expected given the limited role of interest rates in the monetary transmission mechanism, especially in the earlier part of our sample.

\footnotetext{
${ }^{16}$ This finding is confirmed by examining the accumulated impact of exchange rate shocks on monetary base in levels instead of growth rates - there is no statistically significant impact on the level of base money. In contrast, structural shocks to output and prices have a statistically significant impact on base money in levels for several quarters.

${ }^{17}$ The dynamics of the structural shocks do not need to seem identical to the coefficient estimates of the reduced form equations, as the structural shocks are identified by theoretical assumptions about the contemporaneous relationships between the reduced form errors. This explains why the policy reaction to the exchange rate gap is countercyclical in Eq. (2) but the response of base money to a structural shock in the exchange rate is largely insignificant in Figure 2.
} 
We have also estimated the VAR with a different measure of the output gap. Instead of using data on industrial production, we have computed an output gap based on the growth rates of real GDP, with an identical methodology to the one described in Section 2. The SVAR impulse responses are similar to those obtained with the benchmark model: a price shock is met with a procyclical policy response and the response to an output shock is countercyclical although statistically insignificant. An exchange rate shock is also met with a procyclical policy response when real GDP is used. We emphasize that the findings should be treated with caution, taking into account the arguments in favour of the industrial production data in Section 2. The robustness tests provide evidence of the procyclical tendencies of China's monetary policy. Detailed results from all robustness tests are available from the authors upon request.

During the sample period there was a major change in China's exchange rate policy: on July 21, 2005 China announced that it was ending the fixed dollar peg, with a subsequent switch to a peg to a basket of currencies. Shortly afterwards the People's Bank provided more information about the composition of the currency basket: the biggest weights were assigned to the US dollar, the euro, the Japanese yen, and the Korean won. Other minor currencies were also included. But actual policy strongly resembled a crawling peg from July 2005 until the summer of 2008, after which China has kept the value of the yuan stable against the US dollar.

Frankel and Wei (2007) estimate that almost all weight on the currency basket was on the US dollar in 2005 and that the dollar's weight was still "fairly heavy" in $2006 .{ }^{18}$ The investigation tests whether monetary policy setting in China experienced a structural break following the change in the exchange rate regime, by computing a Chow forecast test. Because Candelon and Lütkepohl (2001) show that the standard $F$-test leads to excessive rejections in samples of realistic size, the $p$ values for the test are obtained by bootstrapping methods with 1,000 replications.

There is no evidence of a structural break in the exchange rate in the third quarter of 2005 - the test statistic's $p$-value is 0.51 . Did the change in the exchange rate regime induce a slow change in domestic policy? The analysis tests for a possible structural break on every observation during 2005Q4-2006Q4. All resulting $p$-values are far above those normally considered standard for rejecting model stability. The lowest $p$-value obtained is for 2006Q1 (0.37). The analysis also runs the model until 2005Q2 and performs out-of-sample forecasts 10 quarters ahead. The approach provides an additional test for system stability.

\footnotetext{
${ }^{18}$ Recent estimates support an increasing weight on the euro in the basket, but since September 2008 almost all weight appears to again go to the US dollar (see Frankel, 2009, and http://content.ksg.harvard.edu/blog/jeff_frankels_weblog/2009/03/11/the-rmb-has-now-moved-back-to-the-dollar/).
} 
Formally, an $h$-step-ahead forecast is obtained as

$\hat{x}_{T+h \mid T}=\hat{A}_{1} \hat{x}_{T+h-1 \mid T}+\cdots+\hat{A}_{p} \hat{x}_{T+h-p \mid T},(6)$

where $\hat{x}_{T+j \mid T}=x_{T+j}$ for $j \leq 0$ and the $\hat{A}_{i}$ 's $(i=1, \ldots, p)$ are estimated parameters.

Figure 3 Out-of sample forecast for base money growth (grey solid line)

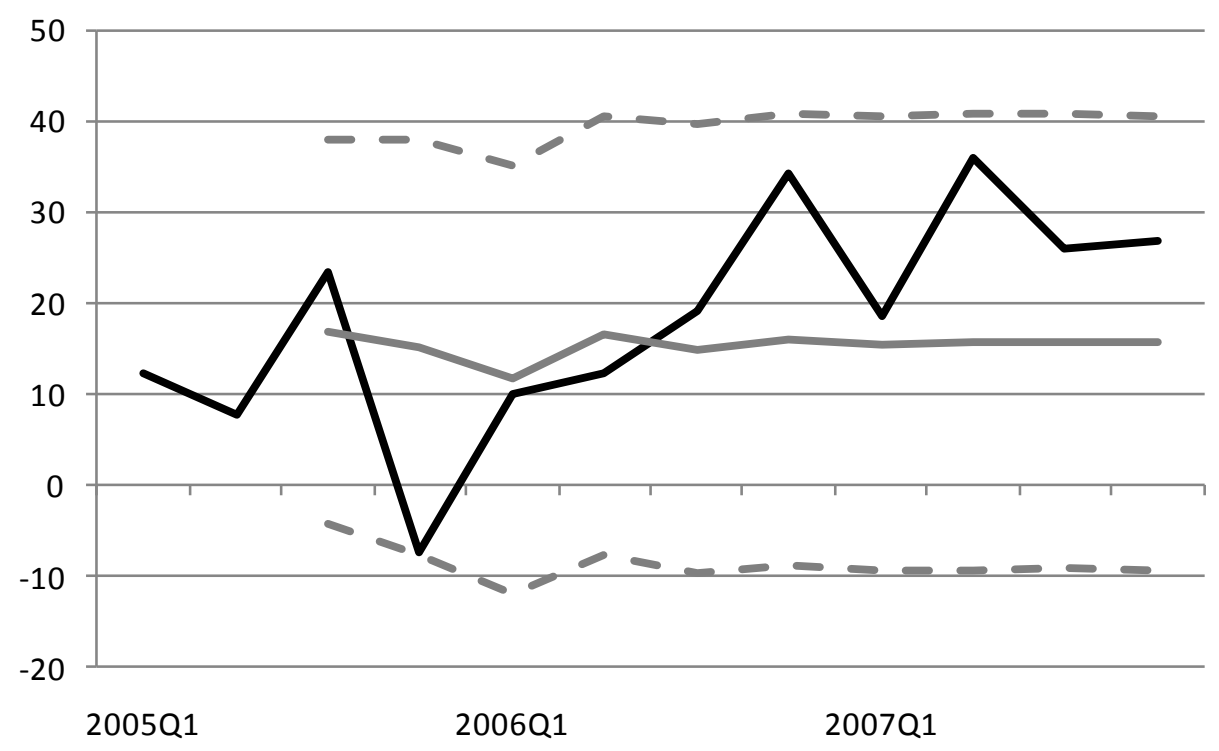

Figure 3 shows that the actual observation for 2005Q4 (solid black line) is just on the borderline of the $95 \%$ confidence intervals (grey dashed lines), while all other actual observations for base money fall inside the confidence bands. This provides further evidence that the exchange rate reform has not entailed a structural change in domestic policy. That also supports the findings in the literature about the relative independence of Chinese monetary policy (e.g. Ma and McCauley, 2008; Liu and Zhang, 2007). 


\section{Monetary policy reactions and survey-based inflation expectations}

The previous analysis considers monetary policy reactions to current and past developments in the relevant variables, but does not explicitly include forward-looking terms. Given the empirically well-established lag between a change in the monetary policy stance - or a policy shock - and output and inflation, including a forward-looking variable in a policy reaction function can be easily justified. ${ }^{19}$ However, the omission of explicit forward-looking terms does not imply that the hybrid rule would not allow for any forward-looking behavior in policymaking. Indeed, if an increase in output gap is expected to lead to inflation pressures with a lag, then by leaning against the wind with respect to output gap the central bank may be reacting to future inflation pressures. This may arise despite the fact that the coefficient on current and past inflation gap signal accommodative policy behavior.

China's surveys on inflation expectations are deficient in terms of sample length. The People's Bank of China publishes a survey on inflation expectations, but the data are available only for the current decade. For that reason the paper employs a business survey on the price level of sales in 5,000 principal industrial enterprises in China, compiled by the People's Bank. ${ }^{20}$ The series reflects the firms' judgments on price developments, including the prospects for the next few months. Most firms in the survey are state-owned large and medium-size enterprises, covering a total of 27 industries. The data are available for the entire sample. ${ }^{21}$ The survey is based on diffusion indices that are quantitative indicators constructed from qualitative answers by firms. The indices are obtained as the difference between qualitative answers indicating either an improving or a deteriorating outlook (an increase or a decrease in sales prices). As the index values range from -100 to +100 , the survey does not produce an actual point forecast for the price level or inflation, but it does capture the perceived and expected dynamics of sales prices. Figure 4 shows the inflation gap and the survey for price level of sales, with both series normalized by their standard deviations.

\footnotetext{
${ }^{19}$ Woodford (2000) discusses problems related to excessive forward-looking reactions in monetary policy.

${ }^{20}$ The People's Bank's survey on inflation expectations is highly correlated with the business survey used in our study for 2001-2008 where both series are available (contemporaneous correlation coefficient of 0.83).

${ }^{21}$ A possible alternative would be to use actual future outcomes for inflation and estimate a forward-looking reaction by GMM, as reported in Zhang (2009). However, our approach relies on surveys on inflation rather than a perfect foresight assumption.
} 
Figure 4 Inflation gap and diffusion index on firms' price level of sales

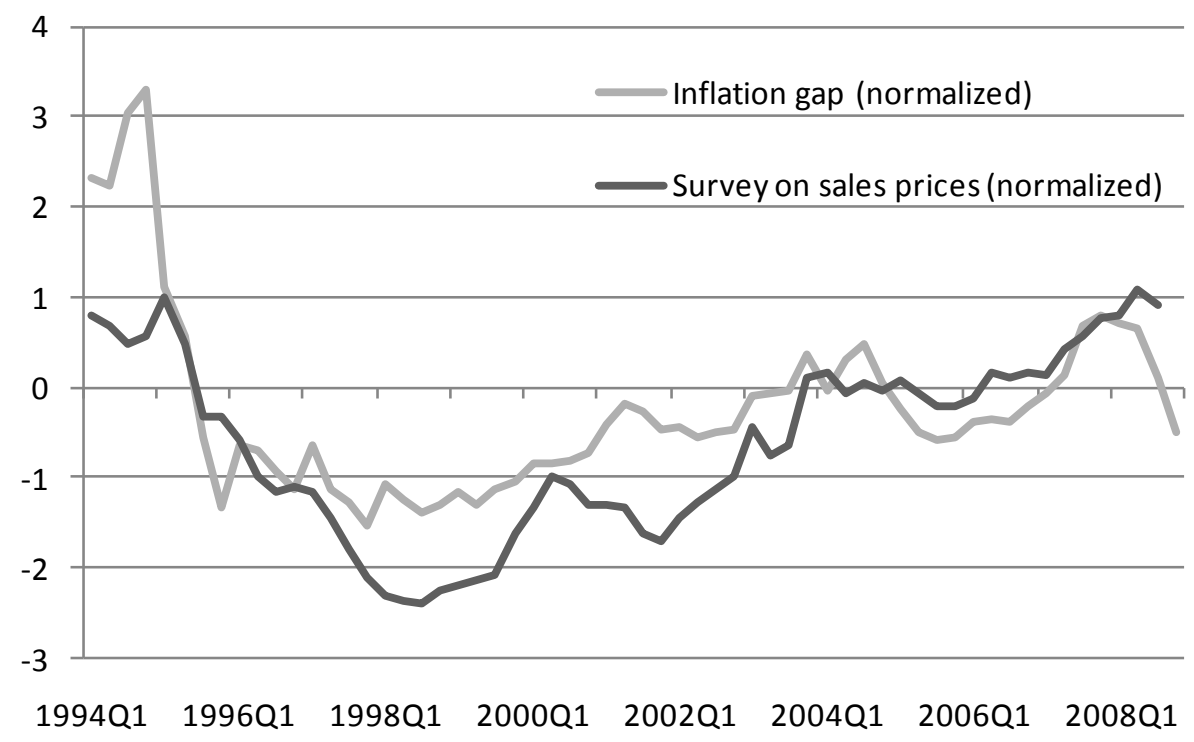

Note: Both series are normalized by their respective standard deviations.

Given the difficulty of simultaneously identifying shocks both in terms of actual inflation and the survey-based measure in a SVAR framework, the modeling focuses on examining a reduced form equation similar to (3), but incorporating the first differences of the price level survey $\left(\pi^{\mathrm{e}}\right)$. The model is estimated using ordinary least squares, eliminating coefficients with $t$-values below 1.00, and estimating the reduced model via feasible generalized least squares. The parsimonious equation for the monetary base is

$$
\begin{aligned}
& \Delta b_{t}=-1.569\left(y-y^{*}\right)_{t-1}+2.541\left(\pi-\pi^{*}\right)_{t-1}-0.200 \Delta b_{t-1}-1.740\left(\pi-\pi^{*}\right)_{t-2}+0.201 \Delta b_{t-2} \\
& \begin{array}{lllll}
(0.965) & (1.078) & (0.114) & (0.861)
\end{array} \\
& -3.651\left(e-e^{*}\right)_{t-2}-0.658 \Delta \pi^{e}{ }_{t-2}+1.982\left(y-y^{*}\right)_{t-3}+0.336 \Delta b_{t-3}+2.798\left(e-e^{*}\right)_{t-3} \\
& \begin{array}{lllll}
(0.974) & (0.433) & (0.912) & (0.117) & (0.920)
\end{array} \\
& -0.645 \Delta \pi^{e}{ }_{t-3}+6.268 \\
& (0.488) \quad(5.070)
\end{aligned}
$$

In equation (7), while the long-run coefficient on the inflation gap is still positive, the one based on survey data carries a negative sign, suggesting that the People's Bank reacts to increases in inflation expectations via restrictive monetary policy. But in equation (7) the output gap carries a 
positive long-run coefficient, which provides some evidence that the countercyclical output gap response identified earlier in the paper actually captures a reaction to inflation expectations.

The analysis considers an alternative measure of inflation expectations computed using an autoregressive univariate model of inflation. An AR(1) model, including a constant term, is estimated as a rolling regression from 1994Q1-1998Q1 to 1994Q1-2008Q4, and at every observation a 4-quarter-ahead out-of-sample forecast is produced. This AR-based measure of inflation expectations does not appear to be statistically significant for the resulting sample of 1998Q1-2008Q4.

\section{Conclusion}

The paper models monetary policy in China using a hybrid McCallum-Taylor reaction function. The estimated reaction function allows feedback from developments in the output and inflation gaps, together with the effective trade-weighted exchange rate, using base money as the instrument. The analysis finds that Chinese monetary policy has been procyclical, reflecting an accommodative reaction to developments in the inflation gap. This is in line with the empirical observation that liberalization policies in terms of reforms and regulation have coincided with increases in lending and inflation. But the reaction to the output gap has been countercyclical, whereas the money supply has not reacted significantly to developments in the exchange rate.

The paper finds stabilizing policy behavior when using business surveys of price developments, suggesting that the People's Bank of China reacts significantly to inflation expectations. The finding is consistent with the estimation of policy reaction functions in a general equilibrium framework, such as Zhang (2009), or in a three-equation New-Keynesian model, as in Liu and Zhang (2007). Similarly, the countercyclical response for the output gap probably reflects reactions to future price developments. 


\section{References}

Amisano, G., Giannini, C., 1997. Topics in Structural VAR Econometrics. Springer-Verlag, Berlin.

Breitung, J., Brüggemann, R., Lütkepohl, H., 2004. Structural Vector Autoregressive Modeling and Impulse Responses. In: Lütkepohl, H., Krätzig, M. (Eds.), Applied Time Series Econometrics. Cambridge University Press, Cambridge.

Burdekin, R. C. K., Siklos, P. L., 2008. What has driven Chinese monetary policy since 1990? Investigating the People's bank's policy rule. Journal of International Money and Finance 27, 847-859.

Candelon, B., Lütkepohl, H., 2001. On the Reliability of Chow-type Tests for Parameter Constancy in Multivariate Dynamic Models. Economics Letters 73, 155-160.

Calvo, G., 1983. Staggered Prices and in a Utility-Maximizing Framework, Journal of Monetary Economics, 12(3), 383-398.

Corden, W. M., 2009. China's exchange rate policy, its current account surplus and the global imbalances. Economic Journal 119, F430-F441.

Dai, M., 2006. Inflation-targeting under a Managed Exchange Rate: the Case of the Chinese Central Bank. Journal of Chinese Economic and Business Studies 4(3), 199-219.

Evenett, S. J. (ed.), 2010. The US-Sino Currency Dispute: New Insights from Economics, Politics and Law. Centre for Economic Policy Research, London.

Frankel, J., Wei, S-J., 2007. Assessing China’s Exchange Rate Regime. Economic Policy 51, 575614.

Frankel, J., 2009. New Estimation of China's Exchange Rate Regime. Pacific Economic Review 14(3), 346-360.

Geiger, M., 2008. Instruments of Monetary Policy in China and Their Effectiveness: 1994-2006. United Nations Conference on Trade and Development, Discussion Paper No. 187.

Granville, B., Mallick, S., 2010. Monetary Policy in Russia: Identifying exchange rate shocks. Economic Modelling 27(1), 432-444.

Holz, C. A., 2004. China's Statistical System in Transition: Challenges, Data Problems, and. Institutional Innovations. Review of Income and Wealth 50(3), 381-409.

Holz, C. A., 2008. China's 2004 Economic Census and 2006 Benchmark Revision of GDP Statistics: More Questions than Answers? The China Quarterly 193 (March 2008), 150-63.

International Monetary Fund, 2003. Deflation: Determinants, Risks and Policy Options - Findings of an Interdepartmental Task Force. International Monetary Fund, Washington, DC.

Koivu, T., Mehrotra, A., Nuutilainen, R., 2009. An analysis of Chinese money and prices using a McCallum-type rule. Journal of Chinese Economic and Business Studies 7(2), 219-235.

Koźluk, T., Mehrotra, A., 2009. The impact of Chinese monetary policy shocks on East and SouthEast Asia. Economics of Transition 17(1), 121-145.

Liu, L-g., Zhang, W., 2007. A New Keynesian Model for Analysing Monetary Policy in Mainland China. Hong Kong Monetary Authority Working Paper 18/2007. 
Ma, G., McCauley, R. N., 2008. Efficacy of China's Capital Controls: Evidence from Price and Flow Data, Pacific Economic Review 13, 104-123.

McCallum, B. T., 1988. Robustness Properties of a Rule for Monetary Policy. Carnegie-Rochester Conference Series on Public Policy 29 (Autumn), 173-203.

Naughton, B., 2007. Chinese Economy: Transitions and Growth. Cambridge, MA: MIT Press.

PBoC, 2005. China Monetary Policy Report, Quarter One, 2005. Monetary Policy Analysis Group of the People's Bank of China. China Financial Publishing House.

Rawski, T. G., 2001. What is happening to China's GDP statistics? China Economic Review 12(4), 347-354.

Rotemberg, J. J., Woodford, M., 1999. Interest-rate rules in an estimated sticky-price model. In: Taylor, J. B., (ed.): Monetary Policy Rules. University of Chicago Press, Chicago.

Sánchez-Fung, J. R., 2005. Estimating a monetary policy reaction function for the Dominican Republic. International Economic Journal 19 (4), 563-577.

Svensson, L. E. O., 1999. Inflation targeting as a monetary policy rule. Journal of Monetary Economics 43, 607-654.

Woodford, M., 2000. Pitfalls of Forward-looking Monetary Policy. American Economic Review 90(2), 100-104.

Zhang, W., 2009. China's monetary policy: Quantity versus price rules. Journal of Macroeconomics $31,473-484$. 
APPENDIX A

Summary statistics

\begin{tabular}{ccccc}
\hline \hline Variable & Mean & Min & Max & Std deviation \\
\hline \hline Inflation gap & -1.233 & -7.202 & 15.399 & 4.430 \\
\hline Output gap & 0.143 & -3.775 & 7.165 & 1.908 \\
\hline $\begin{array}{c}\text { Base money } \\
\text { growth }\end{array}$ & 14.989 & -33.416 & 46.728 & 13.819 \\
\hline Exchange rate gap & -0.167 & -4.116 & 5.726 & 2.324 \\
\hline
\end{tabular}

\section{APPENDIX B}

Impulse responses computed using the benchmark VAR
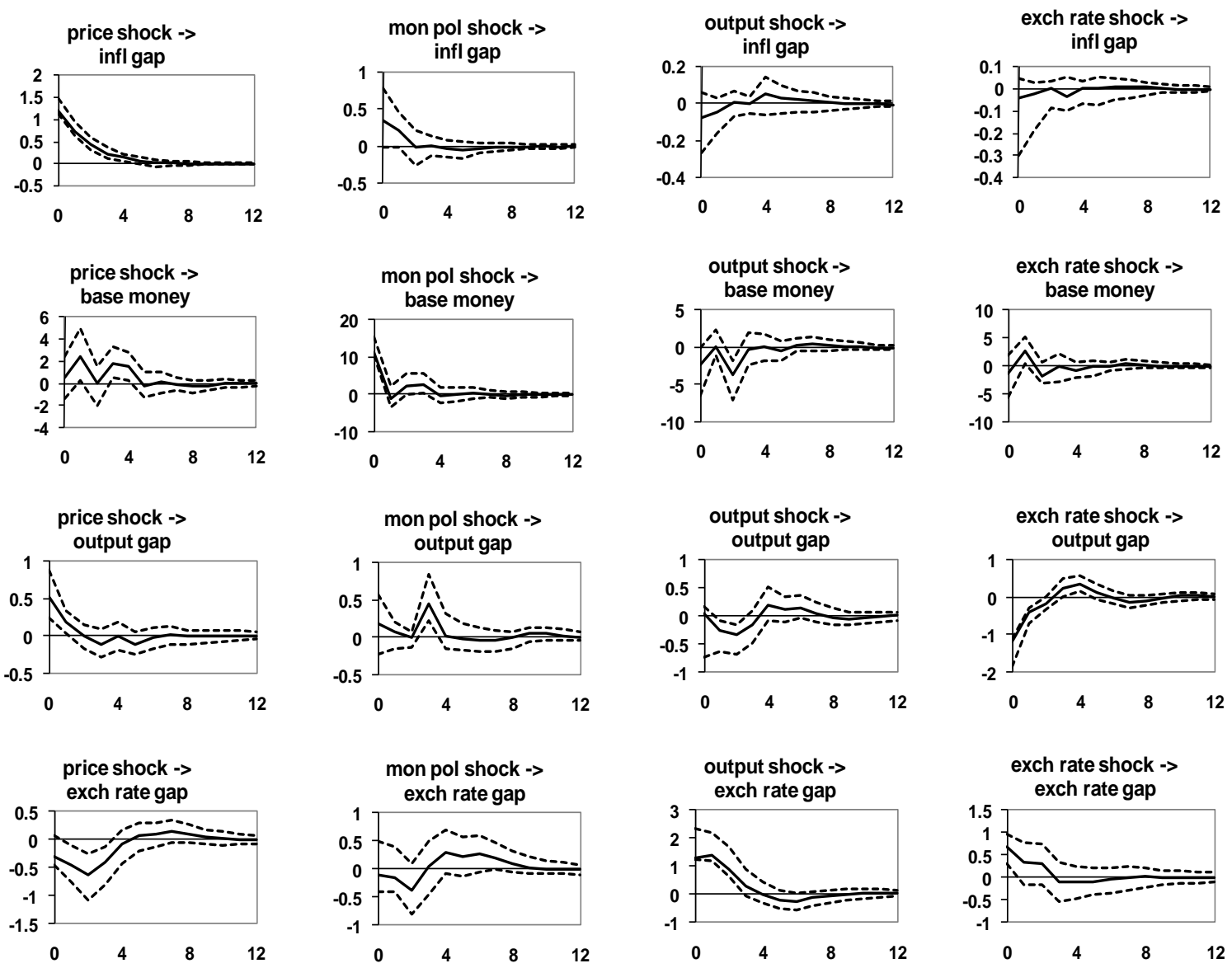
2010 No 1 Anatoly Peresetsky: Bank cost efficiency in Kazakhstan and Russia

No 2 Laurent Weill: Do Islamic banks have greater market power?

No 3 Zuzana Fungáčová, Laura Solanko and Laurent Weill: Market power in the Russian banking industry

No 4 Allen N. Berger, Iftekhar Hasan and Mingming Zhou: The effects of focus versus diversification on bank performance: Evidence from Chinese banks

No 5 William Pyle and Laura Solanko: The composition and interests of Russia's business lobbies: A test of Olson's "encompassing organization" hypothesis

No 6 Yu-Fu Chen, Michael Funke and Nicole Glanemann: Off-the-record target zones: Theory with an application to Hong Kong's currency board

No 7 Vladimir Sokolov: Bi-currency versus single-currency targeting: Lessons from the Russian experience

No 8 Alexei Karas, William Pyle and Koen Schoors and: The effect of deposit insurance on market discipline: Evidence from a natural experiment on deposit flows

No 9 Allen N. Berger, Iftekhar Hasan, Iikka Korhonen, Mingming Zhou: Does diversification increase or decrease bank risk and performance? Evidence on diversification and the risk-return tradeoff in banking

No 10 Aaron Mehrotra and José R. Sánchez-Fung: China's monetary policy and the exchange rate 
Bank of Finland

BOFIT - Institute for Economies in Transition

PO Box 160

FIN-00101 Helsinki

甶 + 358108312268

bofit@bof.fi

http://www.bof.fi/bofit 